\title{
EVALUATION OF SEISMIC PERFORMANCE OF 9 STORY PRECAST BUILDINGS
}

\author{
Phakhin Sangkharat \\ School of Civil Engineering, Suranaree University of Technology, \\ Nakhon Ratchasima, Thailand \\ Mongkol Jirawacharadet \\ School of Civil Engineering, Suranaree University of Technology, \\ Nakhon Ratchasima, Thailand
}

\begin{abstract}
Earthquakes are natural disasters that cause a significant loss of life and property. Chiang Mai is located in the north, with many earthquake faults indicating that Chiang Mai is at risk of an earthquake. This study demonstrates the importance of seismic performance base design of precast concrete buildings (PC). The 10-story apartment precast concrete building be modeled locate in Chiang Mai. The building is designed as per Department of Public Works and Town \& Country Planning DPT1302-18. Buildings will be evaluated for earthquake resistance performance using nonlinear time history analysis, which uses the acceleration of the earthquake recorded from earthquakes of 7 waves. The acceleration of the earthquake will be matched to the design spectrum using ETABS software. Identify the plastic hinge properties of shear walls and moment curvature by using the stress strain model for concrete and steel as specified in Department of Public Works and Town \& Country Planning DPT.1303-14. The results of analysis by the linear static analysis be designed and evaluated by the nonlinear static analysis and the nonlinear dynamic analysis. Including the analysis results from all 3 methods to compare the displacement of buildings, Base shear and Story drift.
\end{abstract}

Keywords: Nonlinear Dynamics Procedure, Nonlinear Time History Analysis, Performance base design, Precast Concrete Buildings, Shear walls.

Cite this Article: Phakhin Sangkharat and Mongkol Jirawacharadet, Evaluation of Seismic Performance of 9 Story Precast Buildings. International Journal of Civil Engineering and Technology, 11(1), 2020, 304-317.

http://iaeme.com/Home/issue/IJCIET?Volume=11\&Issue=1

\section{INTRODUCTION}

Earthquakes are natural disasters that cause loss of life and property because earthquakes can cause the collapse of weak buildings. In recent years, Thailand has experienced more frequent and severe earthquakes, causing damage to buildings. 
Especially in the northern and western regions of Thailand, such as an earthquake in Mae Lao Earthquake 6.3 Richter on May 5, 2014 has affected the damage of many reinforced concrete buildings. Therefore, engineers should attach importance to analysis and design for earthquake resistance.

The construction industry in Thailand is currently growing. To support the expansion of construction Therefore, there is a tendency for the construction of precast concrete systems to increase due to the reduction of construction time when compared with the normal system construction. For earthquake resistant buildings The precast system is not very acceptable because in the past the precast buildings collapsed due to earthquakes such as Emilia Earthquake Magnitude 5.8-6.1 in northern Italy on May 20, 2012 earthquake. That time causing more than 2000 precast buildings to collapse and damaged by the earthquake. The main cause of the collapse is that prefabricated buildings are not designed to be effective in earthquake resistance. (Marco Savoia, Nicola Buratti, \& Loris Vincenzi, 2017) [1]

The design standard code that most engineers in Thailand use for design is the earthquake resistant building design standard DPT.1302-18[2]. In this standard, linear static procedure are recommended for analysis and design. However, the building's design considers the deformation of the building is still in the elastic, but in reality the deformation of the building may also be in the inelastic when an earthquake occurs. The buildings should be strong and tough enough to avoid collapse during a severe earthquake. Therefore, nonlinear dynamics analysis is used to assess the safety of structures designed by assessment standards and to enhance the stability of building structures in areas that may be affected by the vibrations of earthquakes DPT.1303-14 [3]

The objective of this study is to study the seismic efficiency of precast buildings designed as per DPT.1302-18 using linear static procedure, nonlinear static procedure and nonlinear dynamics procedure. The analysis results will be presented in respect of important response parameters including the displacement, base shear and story drift of the structure have been evaluated to determine the overall safety of the structure under demand earthquake.

\section{LITERATURE REVIEW}

Tam (2003) [4] to study the earthquake resistance capability of flat slab reinforced concrete buildings. The 9 story reinforced concrete residential building model and the 15 story office building in Bangkok were evaluated against the earthquake resistance according to the recommendations of ATC-40 [5] and FEMA 273 [6] by nonlinear static pushover. Masonry wall and foundation systems will also be considered. The results show that flat slab reinforced concrete frame has the ability to support lateral force and the lateral displacement at the top of the building is lower than beam-column reinforced concrete buildings. The punching shear failures occur at the slab-column connection inside the building. Also found that the shear wall helps reduce lateral deflection and increase lateral load capacity for buildings.

Kiattivisanchai (2001) [7] To study the earthquake resistance capability of reinforced concrete buildings according to the recommendations of ATC-40 and FEMA 273 by simulating columns-beams reinforced concrete frame buildings then analyzed by Nonlinear static pushover. After that, the strength and toughness of the buildings were analyzed by Capacity Spectrum method and proposed to improve the building to be able to resist earthquake force. Assessment of using a 9 story reinforced concrete building as a residential building in Bangkok The assessment found that the building was able to resistant earthquakes quite well. For the building renovation to be able to resistant earthquakes, it was found that the method used to reduce the distance of reinforcing steel of the beam and increase the crosssectional size. 
That enhances the ability to resistant the maximum lateral forces of the building. As for the longitudinal reinforcement of transverse beams, the building will be able to safely resistant the strongest earthquakes.

Imarb (2002) [8] Conducted an effective study of the analysis, evaluation, and improvement of the earthquake resistance of reinforced concrete buildings by Pushover and Capacity Spectrum as recommended by ATC-40. The model was analyzed using Nonlinear Static Pushover method using SAP2000 program and showed the result of the relationship between the shear force at the base of the building and the lateral displacement in the top of the building (Capacity Curve). The evaluation of a 9 story reinforced concrete building in Bangkok found that building improvements using X-bracing, shear walls and increasing the cross-section of the columns will increase the ability to resistant lateral forces of the building. In addition, improvements by increasing the deformation ability of the building will increase the lateral movement of the building before failure.

Intabooot (2003) [9] Perform analysis, evaluation and improvement of earthquake resistance capabilities of flat-slab reinforced concrete buildings by Pushover and Capacity Spectrum as recommended by ATC-40. For the analysis, the Finite Element Model is prepared which can accurately simulate lateral load behavior and analyze the model using Nonlinear Static Pushover using SAP2000 program. In evaluating 9 story and 30 story flatslabs reinforced concrete in Bangkok, it was found that the masonry walls did not increase the maximum lateral strength but increased the strength of the building before the failure of the masonry walls. Also found that the assessment by El Centro earthquake and earthquakes that may occur around Bangkok. For a 9 story building, the main structure will damage some parts of the building, while the 30 story building behaves in the elastic range and the main structure is not damaged.

Choopool (2004) [10] to study the method of evaluating the earthquake resistance of buildings in Bangkok by Capacity-Demand-Diagram method as recommended by ATC-40. The model was analyzed by Nonlinear Static Pushover using SAP2000. Shows the results in the term of the relationship between the shear force at the base of the building and the lateral displacement in the top of the building (Capacity Curve) and the results of the analysis are compared with the resistance levels and toughness that the building needs. Analysis considered under the ElCentro earthquake and Earthquake data measured at the base of the Baiyoke building. Assessment of earthquake resistance found that buildings with a 9 story height are good and safe in earthquake-resistance. In the case of 20 story buildings, earthquake resistance is at a good and safe level.

Tulay Aksu Ozkul et al.(2019) [11] Analyze the reinforced concrete buildings with shear walls that have been damaged due to the Van earthquake (2011) and determine the damage caused by the analysis of nonlinear time history analysis using Van earthquake acceleration data. Analysis of Time History analysis Analyzed by SAP 2000. It also increases the quality of shear materials and walls designed in accordance with the seismic requirements as per Turkish Seismic Code 2007 [12]. For both buildings, analyze nonlinear time history analysis for the buildings that have been optimized and determine the damage that has occurred. Therefore, comparing the damage between existing buildings and buildings with efficiency enhancement. The results show that the use of appropriate materials and reinforced shear walls can prevent heavy damage.

Pramodini N. and Satish A. (2017) [13] Conducting an assessment of the earthquake resistance performance of a 9 story reinforced concrete residence located in Panaji city of Goa. The building uses the design standards recommended by IS 456:2000 [14]. Assessment of earthquake resistance performance by nonlinear pushover analysis using ETABS v9 program. 
For Moment curvature analysis, based on stress strain, specifying concrete and reinforcing properties. Including the plastic hinge properties of beams and columns as per IS 456:2000. The result of the shear force at the base obtained from the building design is compared with the shear at the base at the desired earthquake force. The response of the building will be in the term of capacity curve, hinge location and ductility ratio used to predict the safety of the building during the desired earthquake force.

Haijuan D. and Mary Beth D. H. (2012) [15] Conducted a study to assess the seismic resistance performance of a 5 story reinforced concrete frame building designed in accordance with the specifications of the Chinese seismic force design standard GB50011-2010 [16]. The analysis uses 7 earthquake acceleration data and matched to the design spectrum. The building is evaluated using two methods of analysis: nonlinear static analysis (pushover analysis) and nonlinear dynamic analysis (time history analysis). Assessment of the efficiency of earthquakes is conducted by Chinese standards. The result shows that the building is designed by GB50011-2010 standard. The analysis shows nonlinear behavior and responses as defined by the understory drift and maximum plastic rotation limits as recommended by ASCE / SEI 41-06 [17]. However, the push over analysis indicates that the potential of a first story mechanism is a soft story. Design recommendations are to help ensure methods strongcolumn, weak-beam damage mechanism.

\section{PERFORMANCE BASED DESIGN}

The current design process is based on estimating seismic requirements and standardized designs, but this design cannot guarantee that the building will meet its intended objectives from the start. Therefore, it is necessary to use the conceptual design of performance by structural engineers. In this method, the evaluation will be made after the initial design, whether the design is for performance objectives or not and finally redesigned and evaluated. Until the desired performance objective is achieved.

In DPT. 1303-14, there are 4 levels of building performance: Operational Level, Immediate Occupancy Level (IO), Life Safety Level (LS) and Collapse Prevention Level (CP). Performance levels under the earthquake are shown in Figure 1.

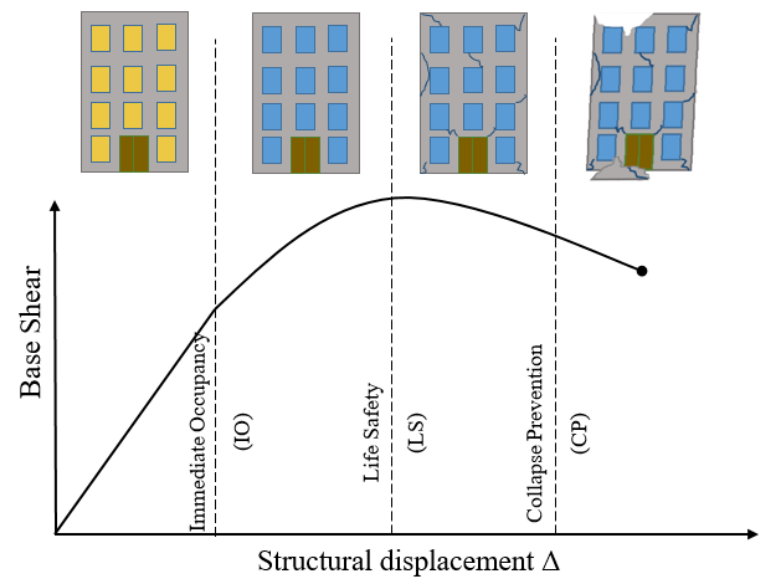

Figure 1 Relationship of building response/damage to member response

Performance evaluations can be performed using static pushover analysis or nonlinear dynamic analysis. For the accuracy of the evaluation, the nonlinear dynamic procedure or nonlinear time history analysis is used. Nonlinear analysis can be performed using the properties of the plastic hinge specified as per DPT. 1303-14. 


\section{METHODOLOGY}

Modeled the 10 story precast reinforced concrete residential building with only the structural wall located in Chiang Mai, which is in zone 2 of the Thai Seismic Segmentation Map, using ETABS v16 program to analyze. Details of the structure and properties of the materials are shown in Table 1 and Table 2 respectively.

In this study, the building will be analyzed and evaluated the building's performance. Including comparisons between linear static procedure (LSP), nonlinear static procedure (NSP), and Time history analysis. Building models are shown in Figure 2 and Figure 3, respectively.

In the standard of DPT. 1303-14 has set the target strength of the building to resistant earthquakes. The buildings in this study are classified as general buildings to provide minimum safety with Basic Safety Objective level (BSO). The buildings may be damaged but not collapse. Buildings must have a life safety performance level under a moderate earthquake with a 225 year return period. These earthquakes are defined as Basic Safety Earthquake (BSE).

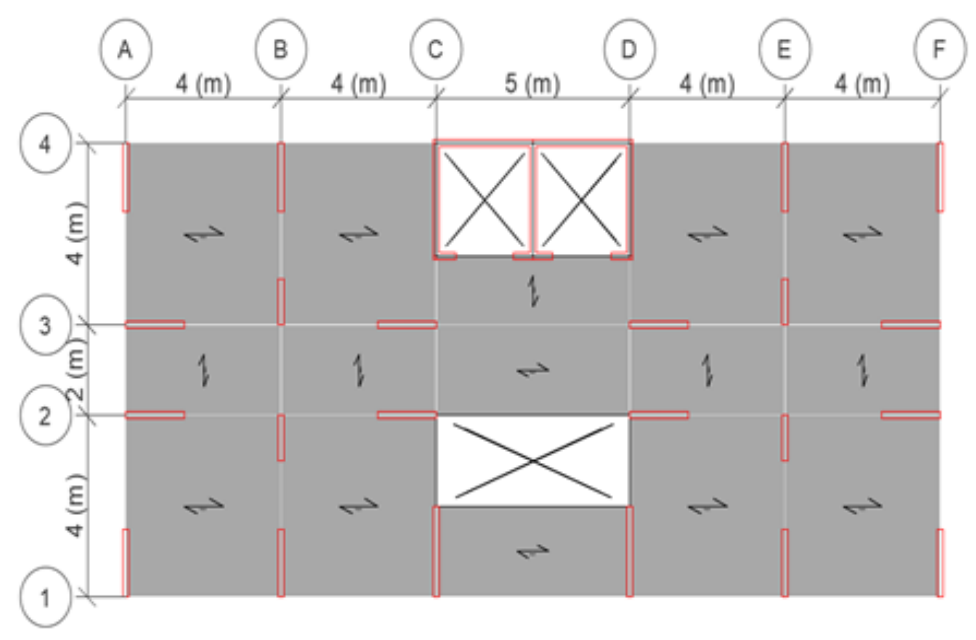

Figure 2 Floor Plan of the precast concrete building

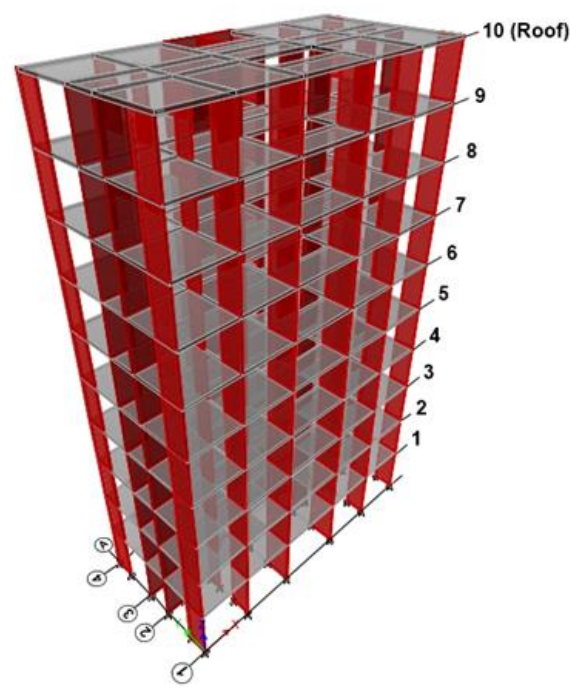

Figure 3 3D View 
Phakhin Sangkharat and Mongkol Jirawacharadet

Table 1 Details of the structure

\begin{tabular}{|l|l|}
\hline Plan Dimension & $10 \mathrm{~m}$ x $21 \mathrm{~m}$ \\
\hline No. of Storeys & 10 storeys $(35.5 \mathrm{~m})$ \\
\hline Structure & Precast Concrete Structures \\
\hline Other Storeys Height & $3.5 \mathrm{~m}$ \\
\hline First Storeys Height & $4.0 \mathrm{~m}$ \\
\hline Base Consideration & Fixed \\
\hline Wall Thickness & $0.30 \mathrm{~m}$ \\
\hline Slab Thickness & $0.20 \mathrm{~m}$ \\
\hline
\end{tabular}

Table 2 Material properties

\begin{tabular}{|l|l|}
\hline Grade of Concrete & C300 \\
\hline Concrete Compressive Strength $\left(\mathrm{f}_{\mathrm{c}}{ }_{\mathrm{c}}\right)$ & $30 \mathrm{MPa}$ \\
\hline Grade of Steel & SD40 \\
\hline Yield Strength $\left(\mathrm{F}_{\mathrm{y}}\right)$ & $392.40 \mathrm{MPa}$ \\
\hline Tensile Strength $\left(\mathrm{F}_{\mathrm{u}}\right)$ & $559.17 \mathrm{MPa}$ \\
\hline
\end{tabular}

\subsection{Linear Static Procedure}

\subsubsection{Gravity Load}

Gravity loads used in linear static analysis and nonlinear analysis are shown in Table .3

Table 3 Gravity Load

\begin{tabular}{|l|l|}
\hline \multicolumn{2}{|c|}{ Gravity Load } \\
\hline \multirow{4}{*}{ Structural Dead Load } & Wall $7.1 \mathrm{kN} / \mathrm{m}^{2}$ \\
& Typical floors $4.7 \mathrm{kN} / \mathrm{m}^{2}$ \\
& Roof $4.7 \mathrm{kN} / \mathrm{m}^{2}$ \\
& Floor Finish $1.5 \mathrm{kN} / \mathrm{m}^{2}$ \\
\hline \multirow{2}{*}{ Live Load } & Typical floors $3.0 \mathrm{kN} / \mathrm{m}^{2}$ \\
& Roof $1.0 \mathrm{kN} / \mathrm{m}^{2}$ \\
\hline
\end{tabular}

\subsubsection{Seismic Load}

The seismic parameters are specified as per DPT. 1302-18 is shown in Table 4.

Table 4 Seismic parameters

\begin{tabular}{|l|l|}
\hline \multicolumn{1}{|c|}{ Type of Soil } & \multicolumn{1}{c|}{ D } \\
\hline Seismic Data & Zone II \\
\hline Damping & $5.0 \%$ \\
\hline Importance Factor $(\mathrm{I})$ & 1.25 \\
\hline Category & $\begin{array}{l}\text { Intermediate Precast Shear } \\
\text { Wall }\end{array}$ \\
\hline Reduction Factor $(\mathrm{R})$ & 4.0 \\
\hline System Over Strength $\left(\Omega_{0}\right)$ & 2.5 \\
\hline Deflection Amplification $\left(\mathrm{C}_{\mathrm{d}}\right)$ & 4.0 \\
\hline $\begin{array}{l}\text { Spectral Acceleration at Period of } 0.2 \mathrm{~s} \\
\left(\mathrm{~S}_{\mathrm{S}}\right)\end{array}$ & $0.963 \mathrm{~g}$ \\
\hline $\begin{array}{l}\text { Spectral Acceleration at Period of } 1.0 \mathrm{~s} \\
\left(\mathrm{~S}_{1}\right)\end{array}$ & $0.248 \mathrm{~g}$ \\
\hline
\end{tabular}




\subsection{Nonlinear Dynamic Procedure}

Nonlinear dynamic procedure, or a time history analysis, is considered a direct dynamics analysis. This is an analysis of the behavior of structures under earthquakes by calculating the building's response at all times when vibration occurs.

This analysis uses earthquake data in terms of ground acceleration as recorded from past earthquakes. The response results will change with time, so this method is called "Time history analysis".

DPT. 1302-18 recommends that appropriate ground acceleration time histories be used at the base of the building should not be less than 3 sets. In this study, 7 ground vibration data are used. Which consists of earthquake data as in Table .5

Table 5 Earthquake data for time history analysis

\begin{tabular}{|l|l|c|c|c|c|}
\hline \multicolumn{1}{|c|}{ Event } & \multicolumn{1}{c|}{ Station } & EQ ID & Year & Magnitude & $\begin{array}{c}\text { Scale } \\
\text { Factor }\end{array}$ \\
\hline $\begin{array}{l}\text { Imperial } \\
\text { Valley }\end{array}$ & El Centro & ECETO & 1979 & 6.53 & 1.2963 \\
\hline $\begin{array}{l}\text { Victoria } \\
\text { Mexico }\end{array}$ & $\begin{array}{l}\text { SAHOP Casa } \\
\text { Flores }\end{array}$ & VICTO & 1980 & 6.33 & 1.9603 \\
\hline Kobe Japan & Kakogawa & KOBE & 1995 & 6.9 & 0.7257 \\
\hline $\begin{array}{l}\text { Northwest } \\
\text { China }\end{array}$ & Jiashi & NOWST & 1997 & 6.1 & 0.5853 \\
\hline Denali Alaska & R109 (temp) & DENLI & 2002 & 7.9 & 2.2789 \\
\hline $\begin{array}{l}\text { Chi-Chi } \\
\text { Taiwan }\end{array}$ & CHY014 & CHICHI & 1999 & 6.2 & 0.9326 \\
\hline Tottori Japan & HRS003 & TOTTO & 2000 & 6.61 & 2.5453 \\
\hline
\end{tabular}

Ground vibrations must be multiplied and adjusted by constant values. Which must make the mean of the response spectrum with a damping ratio of 5\% not less than the response design spectrum throughout the vibrational period between $0.2 \mathrm{~T}$ to $1.5 \mathrm{~T}$ where $\mathrm{T}$ is the fundamental oscillation period of the structure. In ETABS, there is a Matched to Response Function for adjusting the ground vibration data to be used for buildings to match the target spectrum.

\subsection{Plastic Hinges}

The behavior of members can be classified into 2 types which are behavior controlled by deformation (deformation-controlled) or behavior that is controlled by force (force controlled). Which is consider by the relationship between the force and the deformation of members as shown in Figure 4. The relationship in type 1, which is the characteristic of members with ductile behavior. Type 2 has the same characteristics as type 1 , but the difference is the loss of strength and the ability to resistant loads. If there is a relationship between force and deformation as type 3, then the primary and secondary members are considered to have behavior controlled by force. 


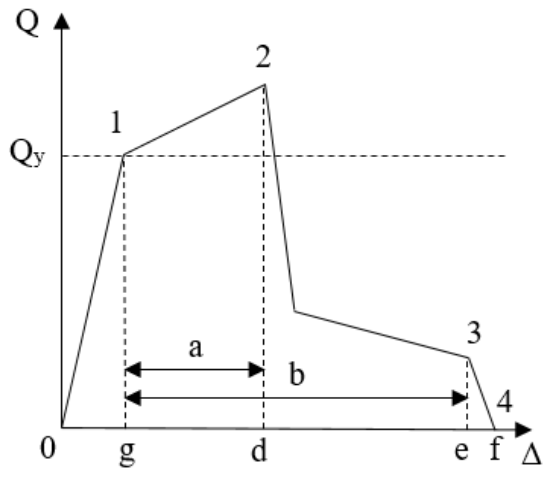

Type 1 curve

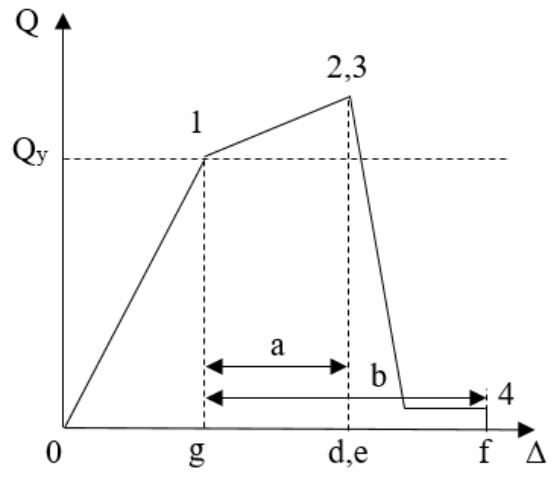

Type 2 curve

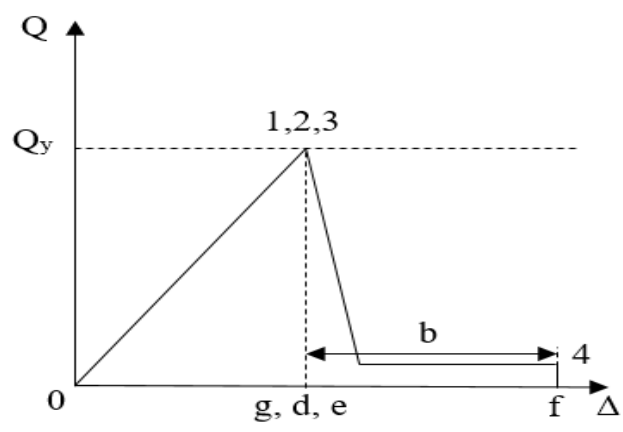

Type 3 curve

Figure 4 Component force versus deformation curves

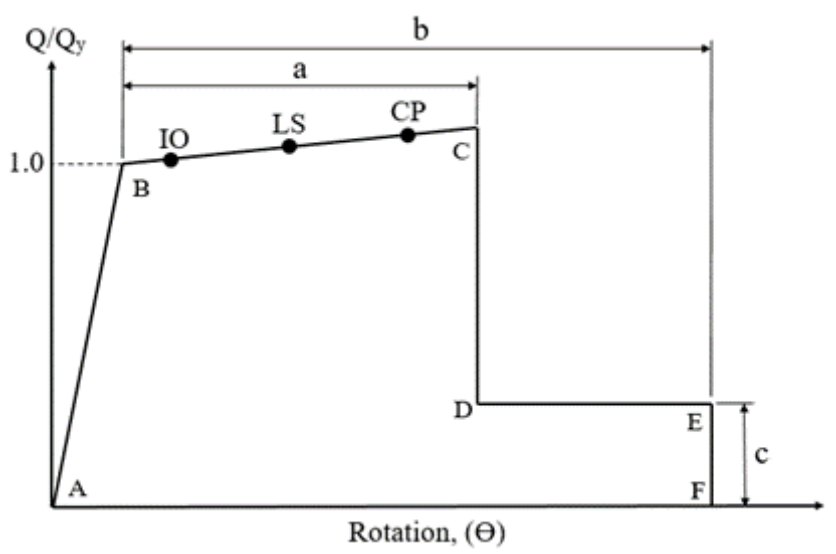

Figure 5 Generalized component force-deformation relations

In this study, the specification of the plastic hinge type to the P-M3 for the Shear wall as specified per DPT. 1303-14. Models and numerical acceptance criteria for nonlinear analysis procedures of shear walls as in Table 6 and Table .7 
Table 6 Modeling Parameters and Numerical Acceptance Criteria for Nonlinear Procedures of Reinforced Concrete Structural Walls and Associated Components Controlled by Flexure

\begin{tabular}{|c|c|c|c|c|c|c|c|}
\hline \multirow{3}{*}{\multicolumn{2}{|c|}{ Conditions }} & \multicolumn{3}{|c|}{ Modeling Parameters } & \multirow{2}{*}{\multicolumn{3}{|c|}{$\begin{array}{c}\text { Acceptance Criteria } \\
\text { Acceptable Plastic } \\
\text { Hinge Rotation (radians) }\end{array}$}} \\
\hline & & \multirow{2}{*}{\multicolumn{2}{|c|}{$\begin{array}{l}\text { Plastic Hinge } \\
\text { Rotation } \\
\text { (radians) }\end{array}$}} & \multirow{3}{*}{$\begin{array}{c}\begin{array}{c}\text { Residual } \\
\text { Strength Ratio }\end{array} \\
\mathrm{c}\end{array}$} & & & \\
\hline & & & & & & rmance & \\
\hline$\frac{\left(A_{s}-A_{s}^{\prime}\right) f_{y}+P}{t_{w} l_{w} f_{c}^{\prime}}$ & $\frac{\mathrm{V}}{\mathrm{t}_{\mathrm{w}} \mathrm{l}_{\mathrm{w}} \sqrt{\mathrm{f}_{\mathrm{c}}^{\prime}}}$ & $\mathrm{a}$ & $\mathrm{b}$ & & IO & LS & CP \\
\hline$\leq 0.1$ & $\leq 0.33$ & 0.008 & 0.015 & 0.60 & 0.002 & 0.004 & 0.008 \\
\hline$\leq 0.1$ & $\geq 0.5$ & 0.006 & 0.010 & 0.30 & 0.002 & 0.004 & 0.006 \\
\hline$\geq 0.25$ & $\leq 0.33$ & 0.003 & 0.005 & 0.25 & 0.001 & 0.002 & 0.003 \\
\hline$\geq 0.25$ & $\geq 0.5$ & 0.002 & 0.004 & 0.20 & 0.001 & 0.001 & 0.002 \\
\hline
\end{tabular}

Table 7 Modeling Parameters and Numerical Acceptance Criteria for Nonlinear Procedures of Reinforced Concrete Structural Walls and Associated Components Controlled by Shear

\begin{tabular}{|c|c|c|c|c|c|c|c|c|}
\hline \multirow[t]{2}{*}{ Conditions } & \multicolumn{3}{|c|}{$\begin{array}{c}\text { Total Drift Ratio (\%), } \\
\text { or Chord Rotation } \\
\text { (radians) }\end{array}$} & \multicolumn{2}{|c|}{$\begin{array}{l}\text { Strength } \\
\text { Ratio }\end{array}$} & \multicolumn{3}{|c|}{\begin{tabular}{|c}
$\begin{array}{c}\text { Acceptable Total Drift (\%) } \\
\text { or } \\
\text { Chord Rotation } \\
\text { (radians) }\end{array}$ \\
Performance Level \\
\end{tabular}} \\
\hline & d & e & $\bar{g}$ & c & $\mathbf{f}$ & IO & LS & $\mathrm{CP}$ \\
\hline$\frac{\left(A_{s}-A_{s}^{\prime}\right) f_{y}+P}{t_{w} l_{w} f_{c}^{\prime}} \leq 0.05$ & 1.0 & 2.0 & 0.4 & 0.20 & 0.6 & 0.4 & 0.75 & 1.0 \\
\hline$\frac{\left(\mathrm{A}_{\mathrm{s}}-\mathrm{A}_{\mathrm{s}}^{\prime}\right) \mathrm{f}_{\mathrm{y}}+\mathrm{P}}{\mathrm{t}_{\mathrm{w}} \mathrm{l}_{\mathrm{w}} \mathrm{f}_{\mathrm{c}}^{\prime}}>0.05$ & 0.75 & 1.0 & 0.4 & 0.0 & 0.6 & 0.4 & 0.55 & 0.75 \\
\hline
\end{tabular}

\section{RESULTS AND DISCUSSIONS}

\subsection{Base Shear and Shear Story}

The results show that the time history analysis by the Victoria earthquake caused the base shear with the highest value of $5518 \mathrm{kN}$ and the linear static analysis caused the base shear to have the smallest value of $2833 \mathrm{kN}$ as shown in Figure 6. In addition, Shear forces were also analyzed using the linear static analysis and the nonlinear static analysis with similar values.

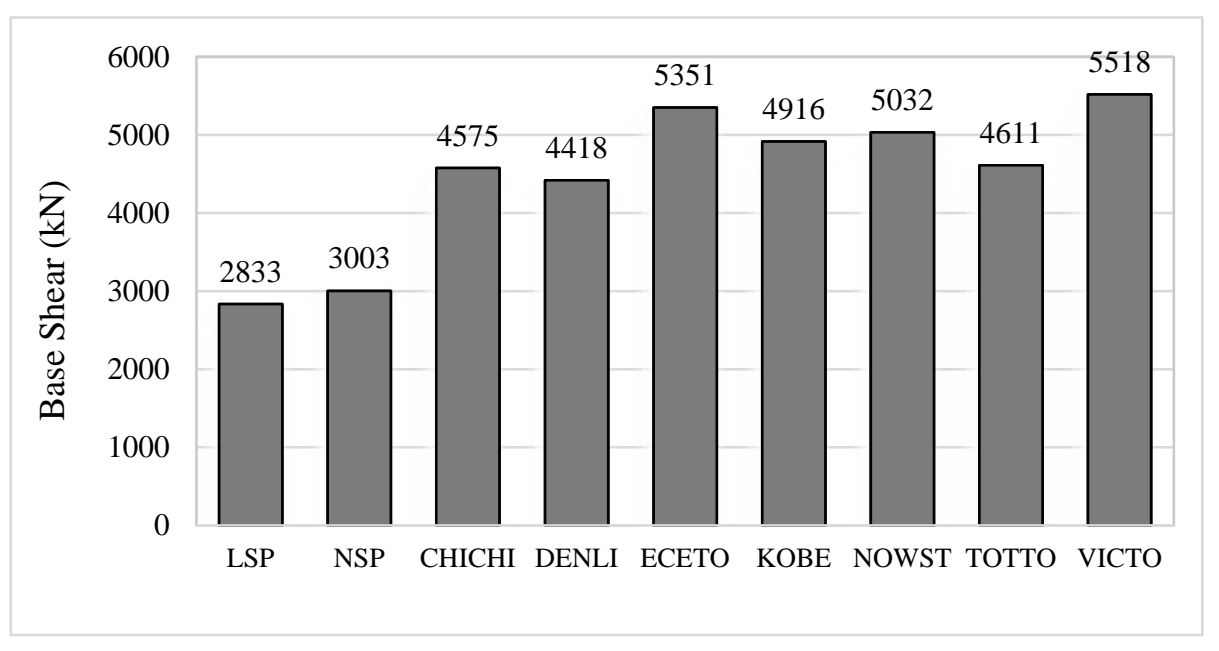

Figure 6 Base shear from the analysis using linear static procedure, nonlinear static procedure and nonlinear dynamics procedure

The shear forces in each storeys are determined by the distribution of lateral forces in accordance with the lateral stiffness of the building in that storeys, and the analysis of the nonlinear dynamics method uses the data for the first vibration mode at 2.414 second. 
The analysis of nonlinear dynamics analysis found that all 7 data Earthquakes are similar. As shown in Figure 7.

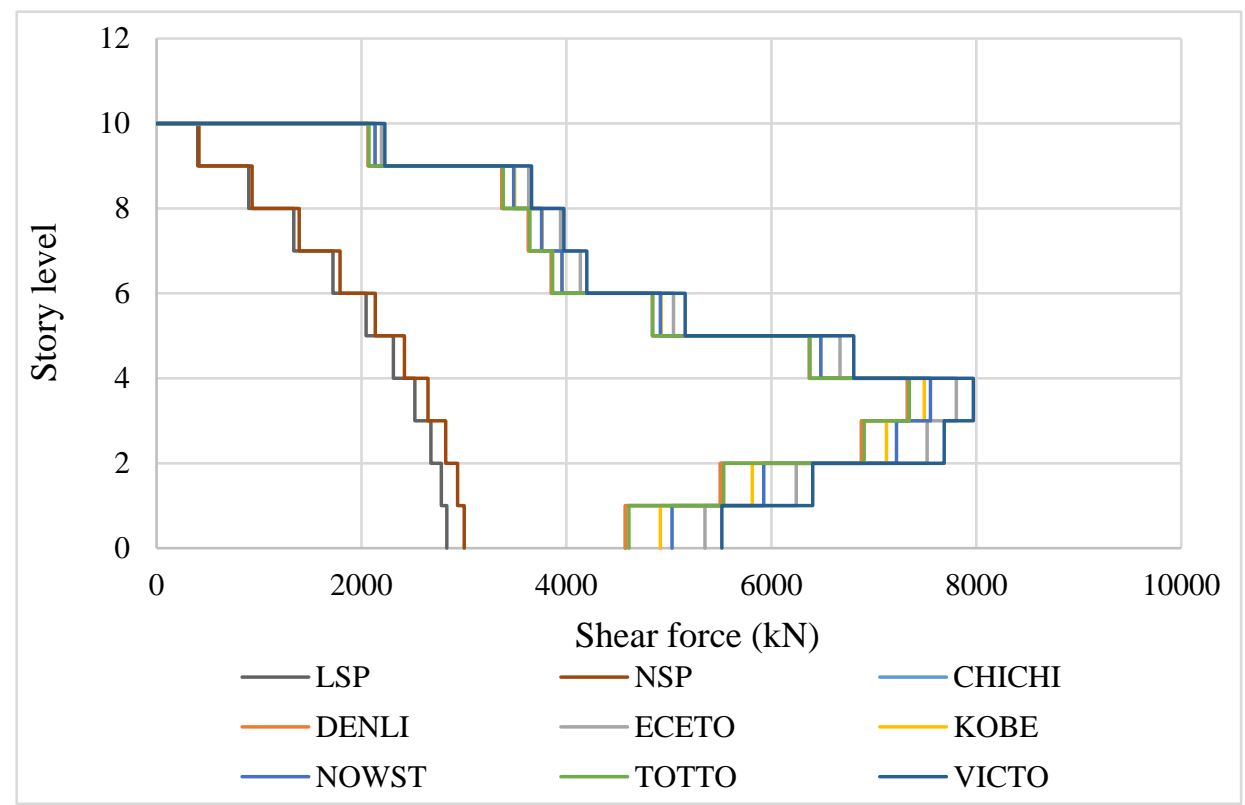

Figure 7 Shear force from the analysis using linear static procedure, nonlinear static procedure and nonlinear dynamics procedure

\subsection{The Result of Displacement at the Top of the Building}

The results showed that the nonlinear static analysis caused the displacement at the top of the building to have the highest value equal to $0.504 \mathrm{~m}$ and the linear static analysis caused the displacement at the top of the building to have the smallest value equal to $0.212 \mathrm{~m}$ as shown in Figure 8. The analysis of the nonlinear dynamics method uses the data for the first vibration mode at 2.414 second. In addition, it is found that the analysis of the nonlinear dynamics analysis for 7earthquakes data that cause displacement at the top of the building were the values between the analysis using the linear static procedure and the nonlinear static procedure as shown in Figure 9.

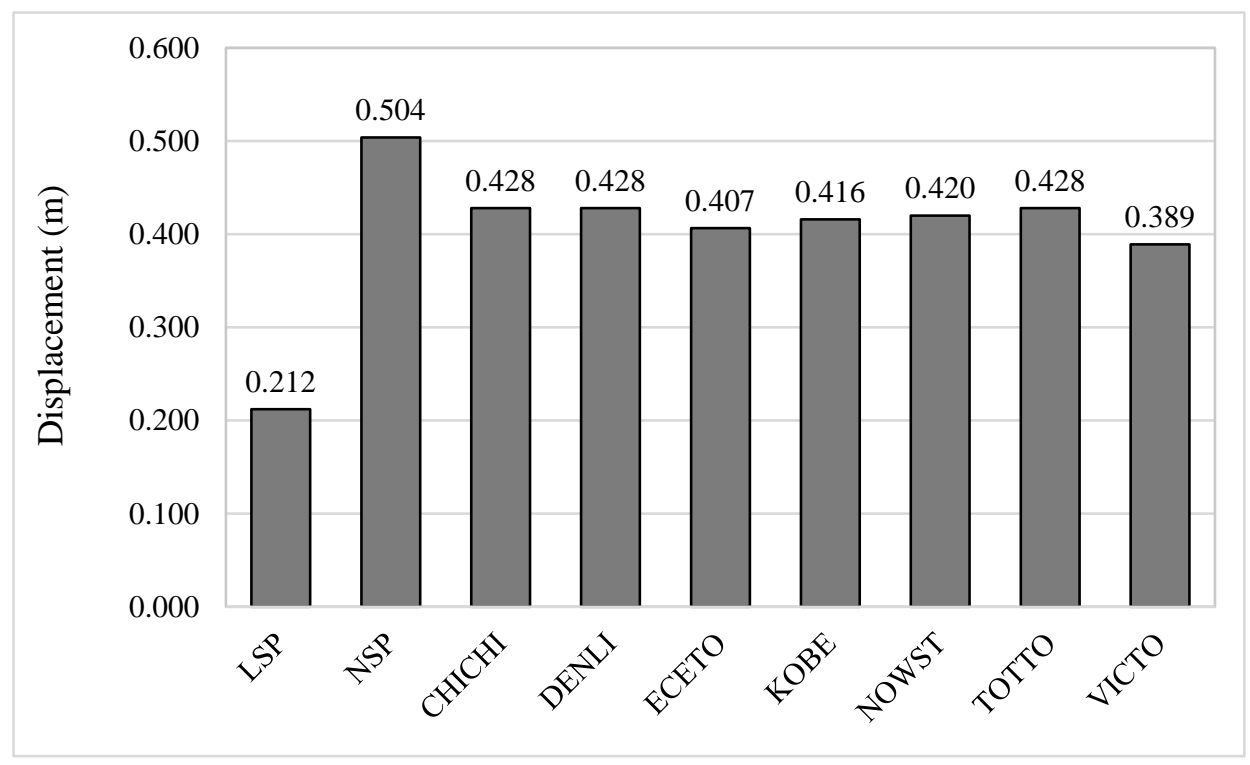

Figure 8 Maximum displacement at the top of the building 


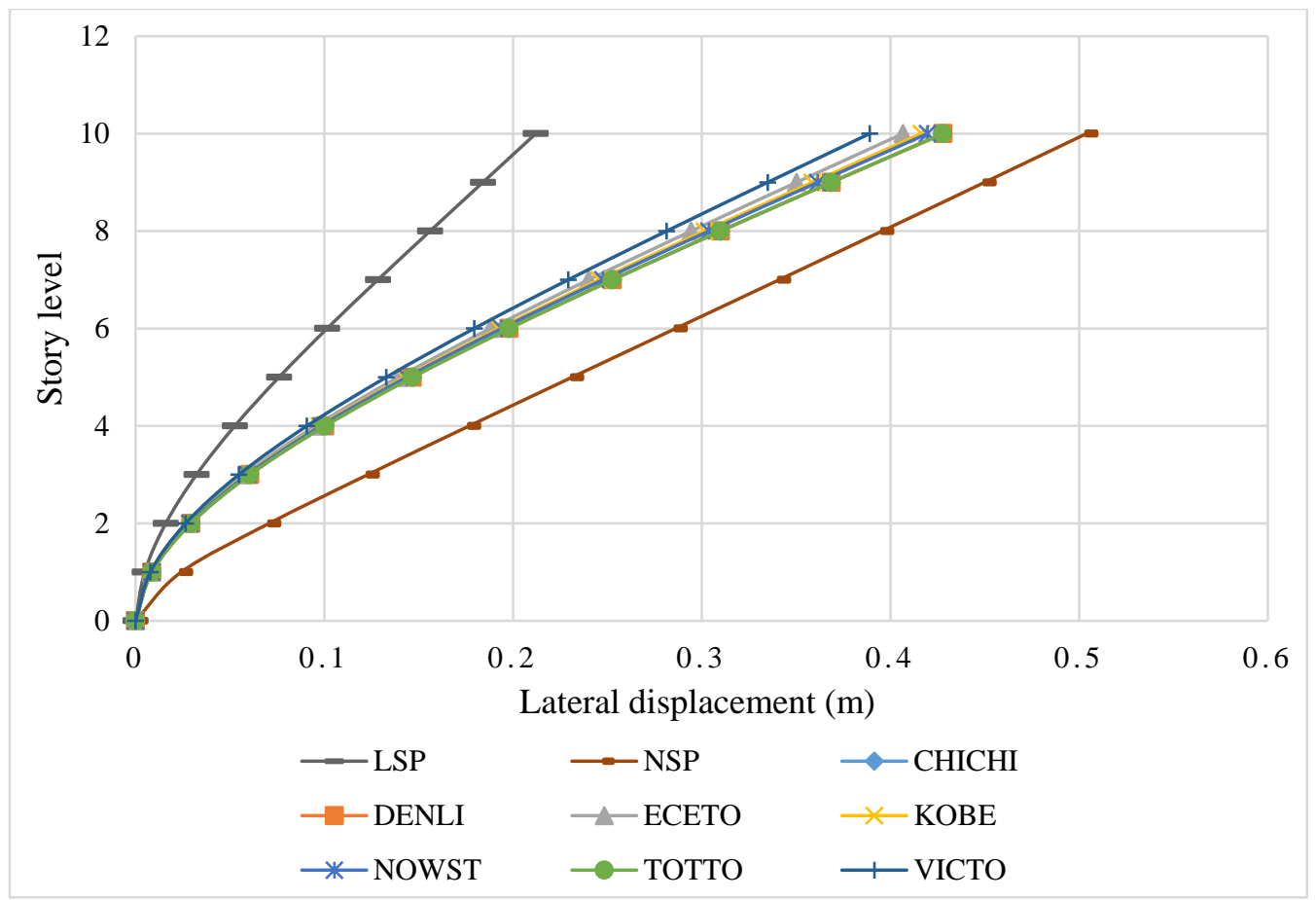

Figure 9 The displacement at the top of the building

\subsection{The Result of Storey Drift Ratio}

The results show that the linear static analysis cause the Storey drift ratio to be the smallest. The analysis of the nonlinear dynamics method uses the data for the first vibration mode at 2.414 second, and also found that in the first story to the 7 level, the analysis using nonlinear dynamics of all 7 seismic data causes the Storey drift ratio to have the value between the linear static analysis and nonlinear static analysis, but in 7 level to 10 level found that nonlinear dynamics analysis has a Storey drift ratio greater than nonlinear static analysis. As shown in Figure 10.

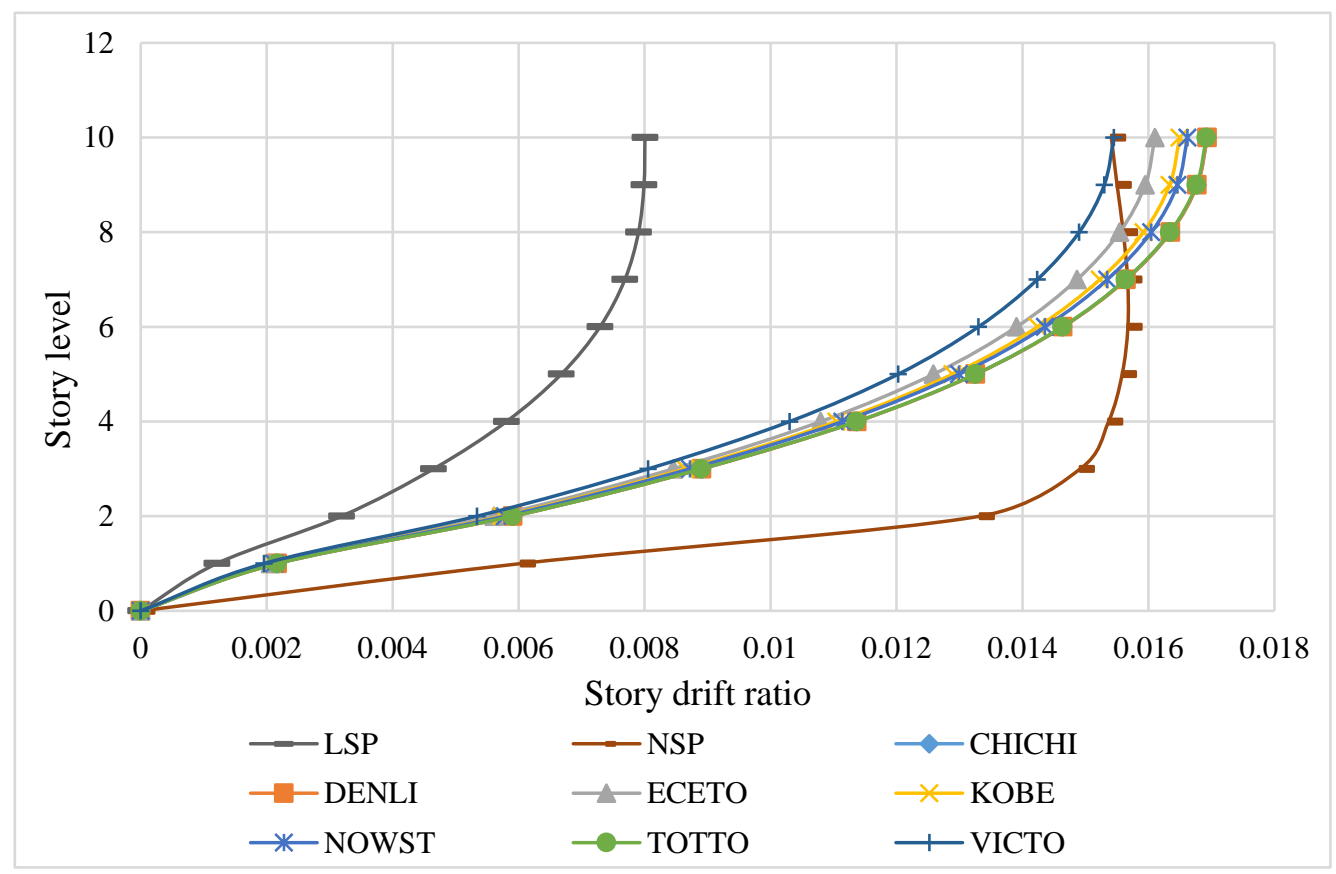

Figure 10 Storey drift ratio 


\subsection{Evaluation of Earthquake Resistance Performance of Precast Concrete Buildings}

The results of the earthquake resistance performance of the precast concrete building showed that the plastic hinge of the shear wall is at the Immediate Occupancy Level (IO) as shown in Figure 11 and Figure 12. Therefore, it is at the level of Better than the target (Life Safety Performance Level) which meets the objectives specified in the standard code (DPT. 130314).

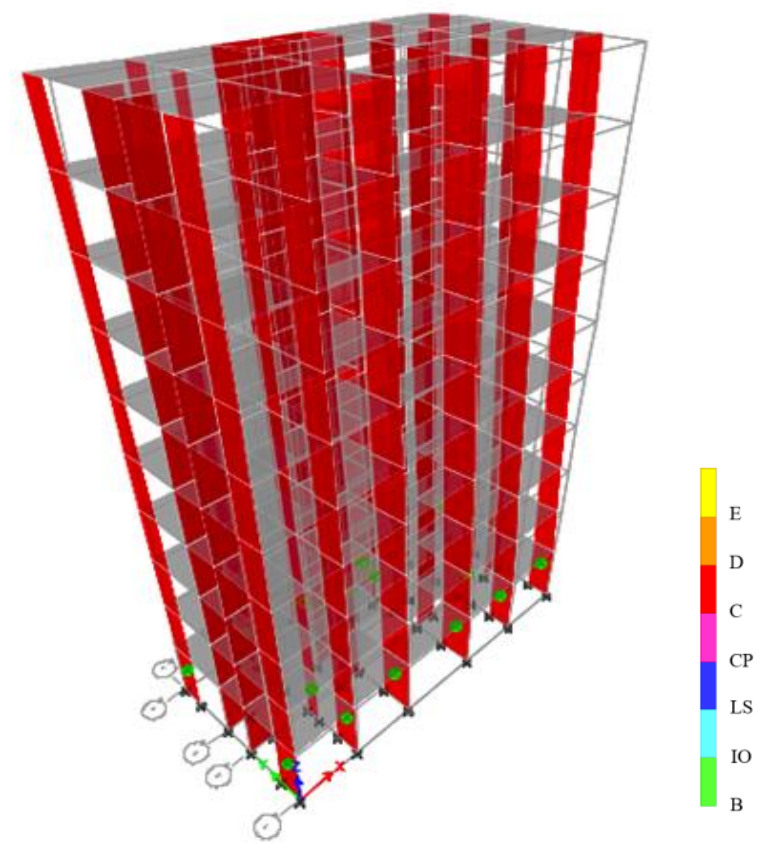

Figure 11 Performance levels of the precast concrete building

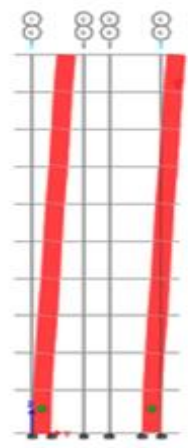
Grid Line A

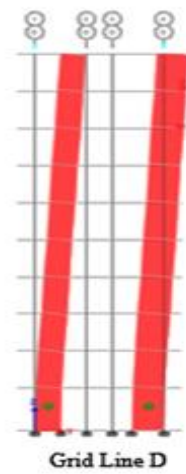

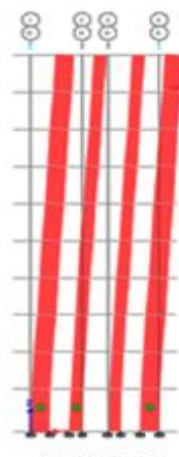

Grid Line B

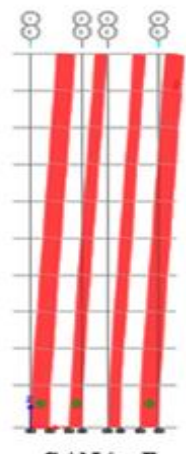

Grid Line E
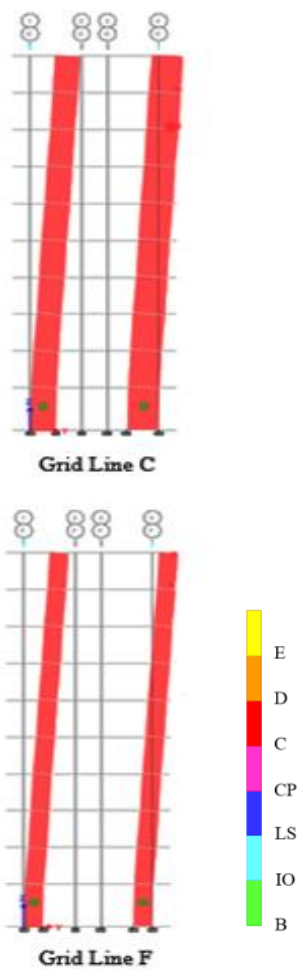

Figure 12 Performance levels of the precast concrete building 


\section{CONCLUSIONS}

The result of the analysis shows that the earthquake resistance building design should consider the selection of the appropriate method of analysis because each method gives different results which can be seen from the base shear, shear story, displacement at the top building and story drift. Linear static analysis has the smallest value because considering the behavior of the structure only in the elastic range, the nonlinear static method and the nonlinear time history method are found to be greater than the linear static method because in the nonlinear analysis. Which the nonlinear method will add deflection amplification $\left(\mathrm{C}_{d}\right)$ in the analysis. Including the determination of the plastic hinge properties of the shear wall, the structural behavior of the inelastic range will be considered, resulting in near-true values.

The results of the building performance evaluation can be seen that the building has a performance level that is better than the desired target. The design may reduce the strength of the building to be economical in construction because in the design of general precast buildings use structural walls fully, evaluating the performance can help to save.

Therefore, it can be concluded that the performance design is a guideline for evaluating the seismic capability of buildings designed for earthquakes. The building design will be inspected to ensure safety in accordance with seismic requirements by analyzing nonlinear time history analysis. Finally, buildings located in the Thai earthquake II can assess the efficiency of the building to be safe and precisely target its performance.

\section{REFERENCES}

[1] Marco Savoia, Nicola Buratti, \& Loris Vincenzi. Damage and collapses in industrial precast buildings after the 2012 Emilia earthquake. Engineering Structures, 137, 2017, pp. $162-180$.

[2] Department of Public Works and Town \& Country Planning, Standard of Earthquake resistant building design DPT. 1302-18. Bangkok, Thailand, 2018.

[3] Department of Public Works and Town \& Country Planning, Standard of Assessment and strengthening of the building Structures in areas of the earthquake zone DPT. 1303. Bangkok, Thailand, 2014.

[4] Tam, N. H. Pushover analysis of reinforced concrete slab-column frame buildings. M.Eng. Dissertation, Asian Institute of Technology, AIT Publications, 2003.

[5] Applied Technology Council, Seismic Evaluation and Retrofitting of concrete Buildings ATC-40. Volume 1 and 2, Seismic Safety Commission, Redwood City, 1996.

[6] Federal Emergency Management Agency, NEHRP Guidelines for the Seismic Rehabilitation of Buildings FEMA-273. Redwood City, California, 1997.

[7] Kiattivisanchai S. Evaluation of seismic performance of an existing medium-rise reinforced concrete frame building in Bangkok. M.Eng. Dissertation, Asian Institute of Technology, AIT Publications, 2001.

[8] Pipat Imarb. Evaluation of Seismic Capacity of Reinforced Concrete Buildings. M.Eng. Dissertation, Thammasat University, 2002.

[9] Nuttawut Intaboot. Evaluation of Seismic Capacity of Reinforce Concrete Flat-Slab Building. M.Eng. Dissertation, Thammasat University, 2003.

[10] Norathape Choopool.Evaluation of Seismic Capacity of Reinforced Concrete Buildings by Considering Beam-Column Details. M.Eng. Dissertation, Thammasat University, 2004.

[11] Tulay Aksu Ozkul, Ahmet Kurtbeyoglu, Muzaffer Borekci, Basak Zengin, \& Ali Kocak. Effect of shear wall on seismic performance of RC frame buildings. Engineering Failure Analysis, 100, 2019, pp. 60-75. 
[12] Turkish Seismic Code, Specification for Buildings to be Built on Seismic Areas, Turkish Ministry of Public Works and Settlement, Ankara, Turkey, 2007.

[13] Pramodini Naik, \& Satish Annigeri. Performance Evaluation of 9 Storey RC Building Located in North Goa. Procedia Engineering, 173, 2017, pp. 1841-1846.

[14] IS 1983 (Part 1), Criteria for Earthquake Resistant Design of Structures, Bureau of Indian Standards, New Delhi 110002, 2002.

[15] Haijuan Duan, \& Mary Beth D. Hueste. Seismic performance of a reinforced concrete frame building in China. Engineering Structures, 41, 2012, pp. 77-89.

[16] National Standard of the People's Republic of China, Code for seismic design of building (GB50011-2010). China Architecture and Building Press, 2010.

[17] ASCE. Minimum design loads for building and other structures (ASCE/SEI 7- 10). American Society of Civil Engineers, 2010. 